\title{
The Evolution of Kotex Advertising and the Introduction of the 'Negro Market'
}

\section{Adriana Ayers}
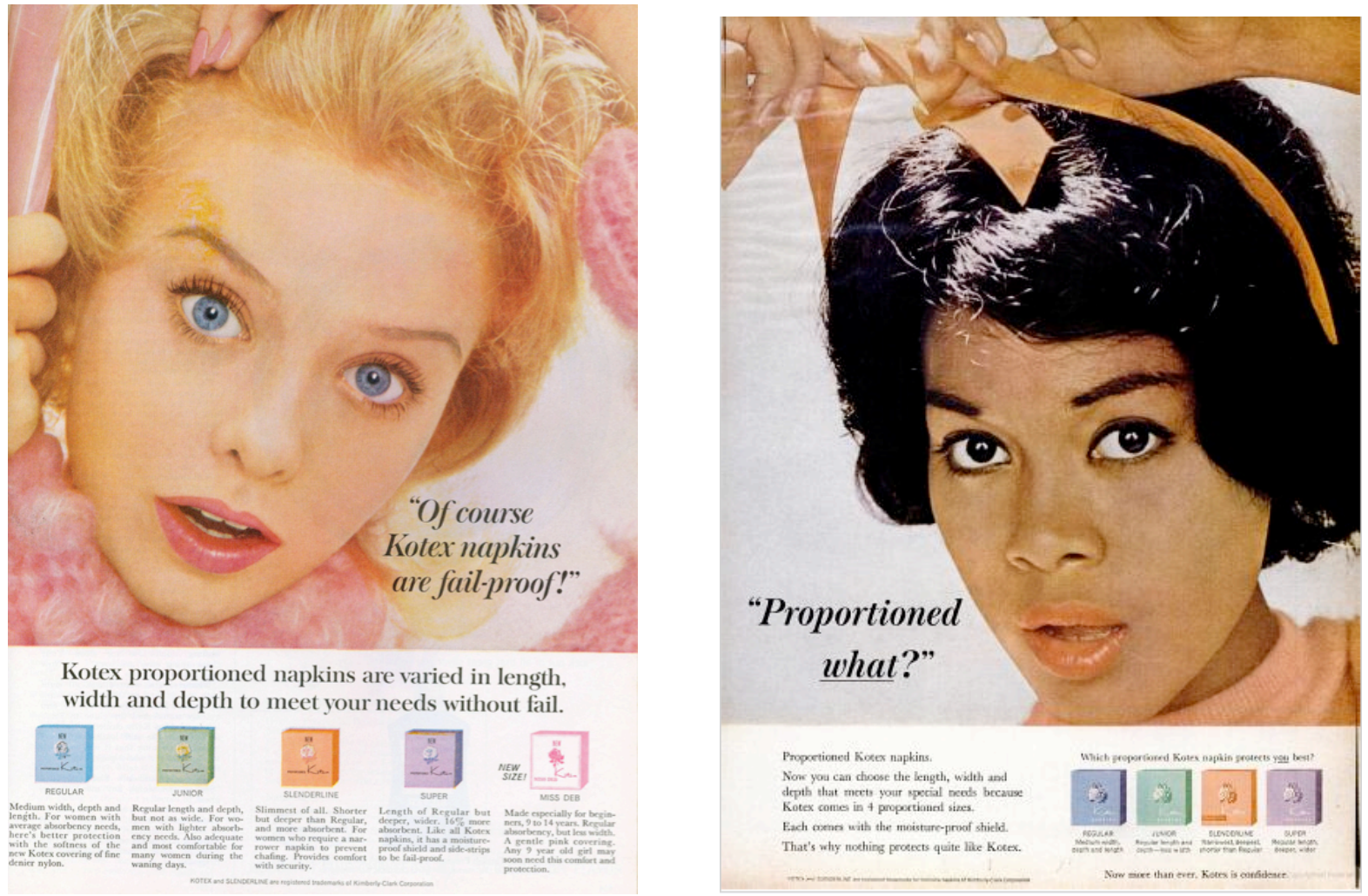

\section{Abstract}

Adriana Ayers studies the evolution of kotex advertising, focusing specifically on the way in which African American women were figured into changing advertisers' conceptions of womanhood. The article analyzes images featured in various women's magazines to examine how ideas surrounding menstruation were packaged and sold to women.

Throughout the history of menstrual products advertising, companies have shifted their ads to respond to contemporary ideologies. It was not until the Civil Rights movements of the 1960s and the push towards emancipation and equality for all women that advertisers responded by introducing campaigns to a new, previously ignored market. The first Kotex advertisement featuring a black model was printed in the November 1962 issue of Ebony magazine. ${ }^{1}$ The medium-light skinned model is shown tying a bright orange bow into her

1 See cover page for both images.

Left: Kotex advertisement, general magazine placement (1964). 
straightened hair, surprised by Kotex's announcement of newly proportioned options. In Good Housekeeping's November 1962 issue, the same advertisement is shown, only with a blonde, white model. She too is tying a bow in her hair, surprised by Kotex's new products. She projects the same youthful naivety as her African American counterpart. These parallel advertisements demonstrate the first movement towards acceptance of black women as consumers by recognizing the quality of attention to be paid to each demographic. ${ }^{2}$ According to Sharra L. Vostral, in her book Under Wraps: a History of Menstrual Hygiene Technology, the ad itself is not particularly noteworthy in terms of style or content. However, from my own analysis, prior to November 1962, Kotex advertisements strictly featured white women in glossy, full-page spreads (see figure three). African American women have been effectively unacknowledged from all the dialogue surrounding early to mid-20th century discourse on menstruation, feminine hygiene products, and advertising. It was not until the 1960s that African American women were introduced as a viable market to major manufacturers and advertisers, such as Kotex. By discussing how language and images reflected beliefs and ideologies of the time, I will provide a study of the evolution of the gendered and racialized discourse on disposable hygiene product's advertisements by major manufacturer Kotex. Furthermore, I will discuss how that discourse did not change with the introduction of the new 'negro' market in the 1960 s, but rather co-opted black women into the pre-existing gendered discourse with techniques such as "duplicate advertising." Due to the inherent lack of secondary sources concerning this topic, a large section of this article will rely on my own analysis and examination of multiple menstruation advertisements as found in Ebony magazine. ${ }^{4}$

The primary goal of these advertisements was to convince consumers that they needed to purchase these products. By persuading women that their menstruation was a problem--whether as concern of personal hygiene or the conservation of one's femininity-advertisers and manufactures could ensured a constant source of revenue. ${ }^{5}$ Furthermore, these advertisements showed "menstruation [did] not

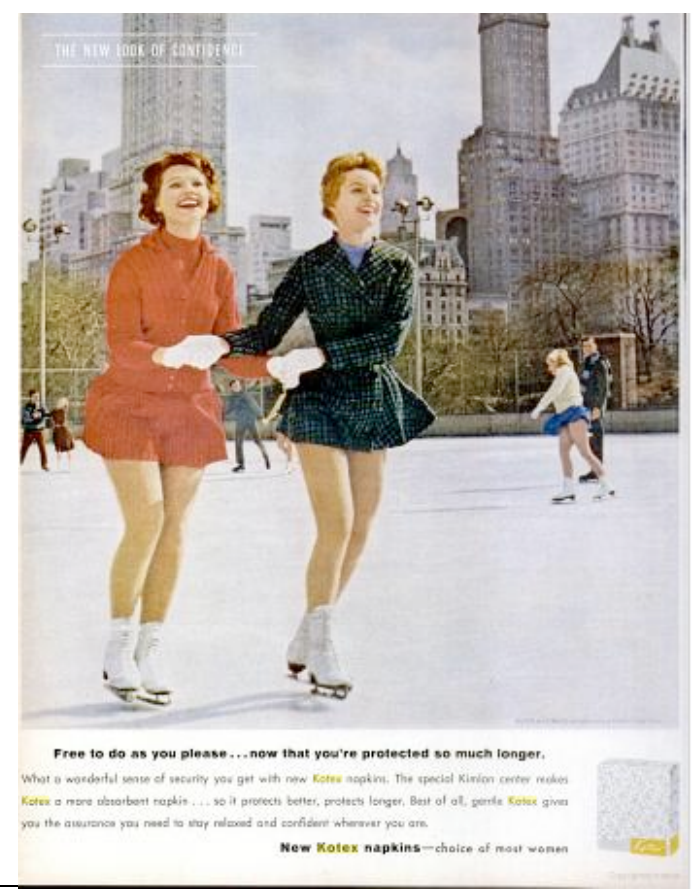

It should be noted, that due to strict copyright laws on all Hearst.owned magazines, including Good Housekeeping; I did not have access to the original advertisemen FidguHfA 3.

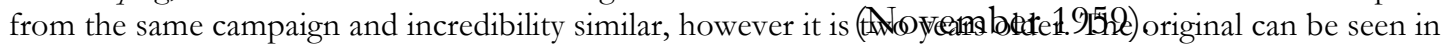
Sharra L.Vostral, Under Wraps: A History of Menstrual Hygiene Technology (Lanham: Lexington Books, 2008), 95. Right: Kotex advertisement, Ebony (November 1962).

${ }^{2}$ Vostral, 147.

${ }^{3}$ Laila Haidarali, "Polishing Brown Diamonds," from Unequal Sisters: An Inclusive Reader in U.S.Women's History $4^{\text {th }}$ ed. Edited by Vicki L. Ruiz and Ellen Carol DuBois.(New York: Routledge, 2008), 540.

${ }^{4}$ Ebony magazine offers a large section of their archived magazines online (1959-current) http://www.ebonyjet.com/Archive.aspx

${ }^{5}$ Elizabeth Arveda Kissling, Capitalizing on the Curse: The Business of Menstruation (Boulder: Lynne Rienner Publishers, 2006), 11-12. 
make women impure or dirty; they menstruate[d] because they [were] dirty or impure. Because such uncleanliness [could not] be stopped or prevented, it [should] be hidden." Thus, the same companies who offered the solutions had manufactured the problems of women's bodies. It is important to realize that men dominated the advertising industry, like most contemporary industries. Consequently, advertisements can reveal both subtle and overt examples of male dominance and language that has always been associated with embarrassment and secretiveness - secrets that are not just kept, but kept from someone else, in this case, men.

By the 20th century, magazines such as Good Housekeeping and Ladies Home Journal were places many women would turn for trusted advice. ${ }^{8}$ Specifically, Good Housekeeping used experts to assert their "authority on all aspects of home life" and to establish guarantees on the products they advertised.' Ranking as the nation's third most popular magazine, its demographic was mostly white women from small to mid-sized towns who, according to the magazine's editor, Daniel Henderson, were "generally a little better educated than the average [woman], without being sophisticates or 'in' members of any intellectual elite." ${ }^{10}$ The popularity of these types of magazines coincided with the booming consumer and advertising industry, which created products they thought reflected public tastes, and campaigns designed to complement the nation's opinions. ${ }^{11}$ By the 1920s, changes in the discourse surrounding women's bodies and menstruation were highlighted in the new products available. More women began using homemade disposable napkins, as opposed to the potentially disease-ridden re-usable cloth diapers. ${ }^{12}$ In the aftermath of the First World War, and in light of various public health campaigns, discussions surrounding menstruation became more acceptable in certain groups. ${ }^{13}$ Health and hygiene were the main areas of concern for women and ads coexisted alongside the national health campaigns for cleanliness. For example, products such as

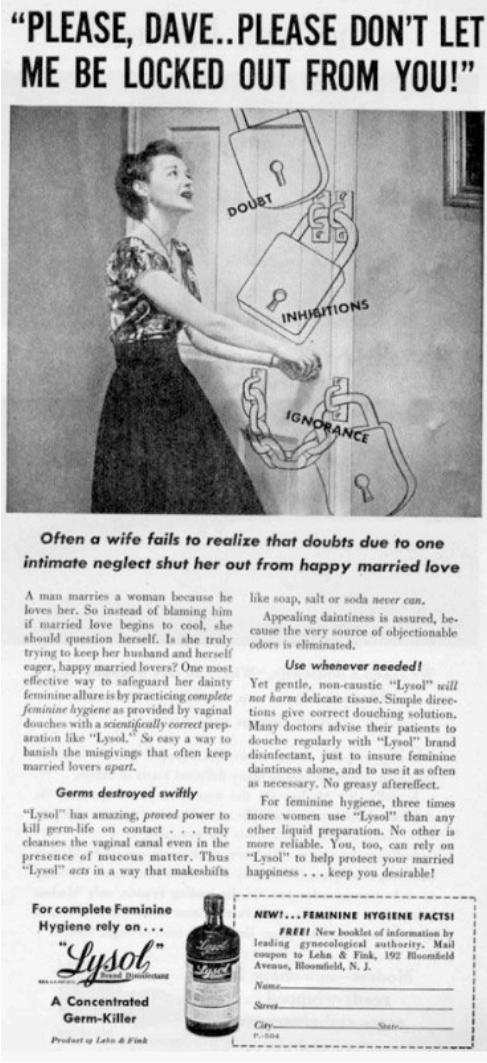

Figure 4: Lysol, general magazine placement (exact year unknown).

\footnotetext{
${ }^{6}$ Kissling, 10.

${ }^{7}$ David Linton, "Men in Menstrual Product Advertising - 1920-1949," Women and Health 46 (2007): 99-100, emphasis in the original.

${ }^{8}$ Kim Chuppa-Cornell, “Filling a Vacuum: Women's Health Information in Good Housekeeping's Articles and Advertisements, 1920-1965," The Historian (September 2005): 456.

${ }^{9}$ Cornell, 455-56. Good Housekeeping stamped their advertised products with an "in house seal of approval."

${ }^{10}$ Cornell, 456.

${ }^{11}$ Cornell, 458.

${ }^{12}$ Joan Jacobs Brumberg, The Body Project: An Intimate History of American Girls (New York: Random House), 1997.116.

${ }^{13}$ These groups included certain public school settings, girls' groups and female-targeted magazines. Brumberg, 45 .
} 


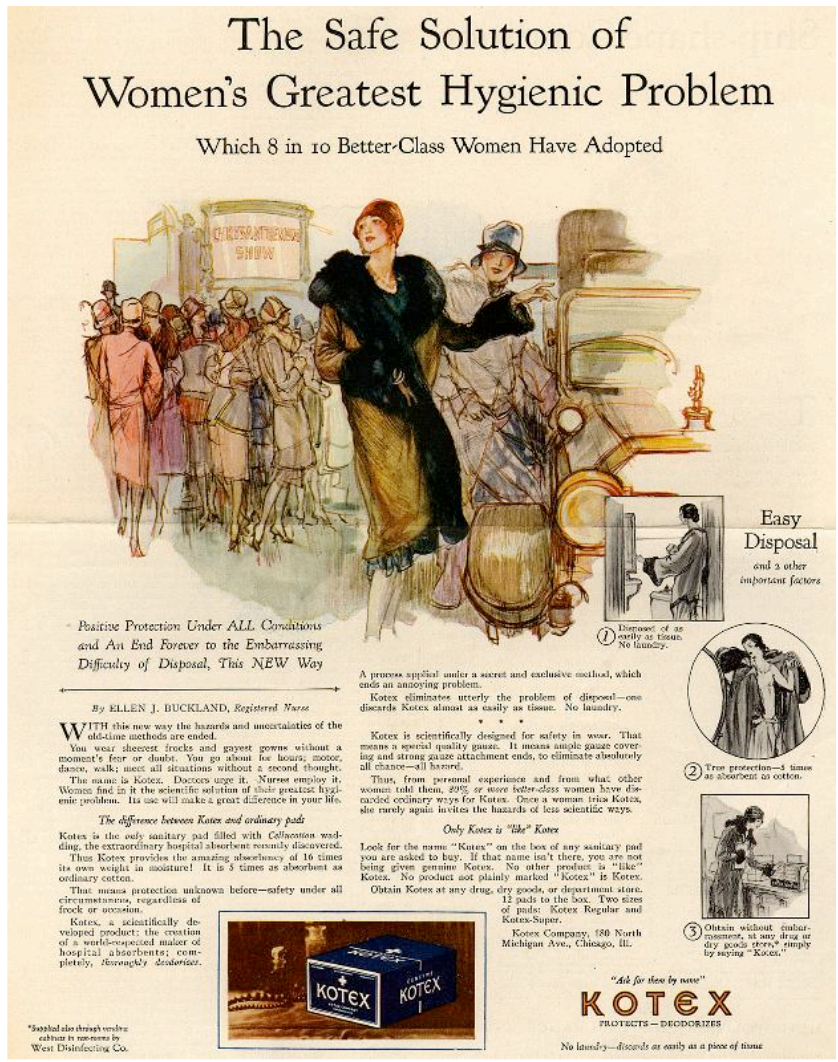

Figure 5: Kotex advertisement, Saturday Evening Post (1927).
"Lysol" were introduced to encourage regular "necessary preventative measures." Advertisers suggested it was "a safe and effective antiseptic" for both the homes of American women and their most "delicate internal tissues." 14

In the case of newly manufactured disposable menstruation products, these exclusively male advertisers emphasized their perceptions of menstruation and the women experiencing it. ${ }^{15}$ Because most women relied on homemade napkins, effective advertising would be necessary in order to establish the reputations of these new products. Interestingly, these companies ran more campaigns in women's magazines than any other female product. $^{16}$ These advertisements described women as abnormal, unclean, unhealthy, and in need of a medical solution (see figure 5). ${ }^{17}$

The aftermath of the First World War forced major paper manufacturer company, Kimberly-Clarke, to find creative ways to get rid of the stockpiles of leftover cellulose wrappings used as bandages in the war. Absorbent and inexpensive, the new product made from these bandages would revolutionize the way women responded to their menstruation. The result of this project was the disposable sanitary napkin manufactured under the name Kotex. In the advertising that followed, these products promised to make women's bodies more hygienic, more feminine and thus, more socially acceptable. Within the advertising for these new products, women's bodily functions were described as defective and unnatural; only by using Kotex products could one be considered socially acceptable. In a sense, they were selling socially acceptable femininity. ${ }^{18}$

\footnotetext{
${ }^{14}$ Shelley M. Park, "From Sanitation to Liberation?: The Modern and Postmodern Marketing of Menstrual Products." Journal of Popular Culture (2003): 154-55.

${ }^{15}$ Karen Houppert, The Curse: Confronting the Last Unmentionable Taboo: Menstruation (New York: Farrar, Straus and Giroux, 1999), 9.

${ }^{16}$ Cornell, 461.

${ }^{17}$ Park, 150.

${ }^{18}$ Elana Levine, “'Having a female body doesn't make you feminine': Feminine Hygiene Advertising and 1970s Television." The Velvet Light Trap 50, Fall 2002: 37.
}

Constellations

Volume 2, No. 2 (Winter 2011) 
In January 1921, the first Kotex advertisement appeared in the Ladies Home Journal, depicting two women, a nurse and a wounded veteran. This was the "first real public acknowledgment of menstruation." 19 The image implied the idea of menstruation as a debilitating illness, associating it with returning soldiers from the bloody European front. It also showed sanitary napkins as a medical product, each box displaying the Red Cross symbol. ${ }^{20}$ Wallace Meyer, the creator of the first printed ads for Kotex, understood that discretion was necessary and made no mention of the words sanitary napkin. ${ }^{21}$ Interestingly,

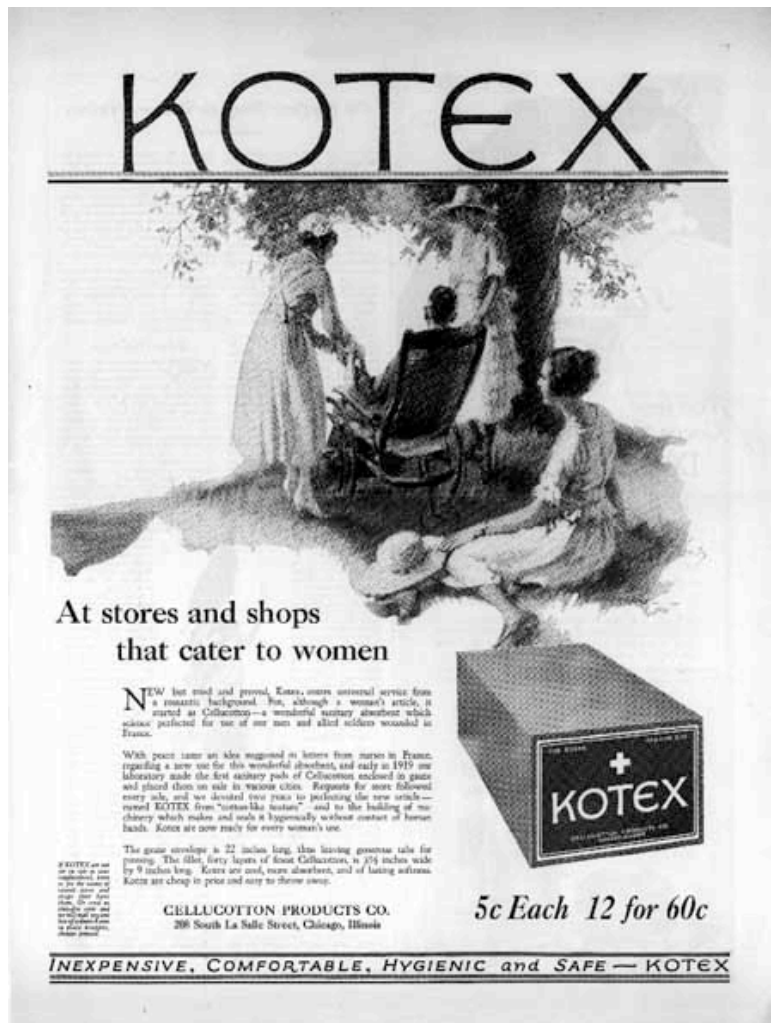

Figure 6: Kotex advertisement, Ladies Home Journal (January 1921).

Prior to World War One, most working-class women did not have the disposable income to purchase these commercially-made products. However, in less than 10 years, Kotex firmly established itself as a basic necessity in women's lives and, consequently, between 1929 and 1937, sanitary napkin sales actually increased, despite the economically crippling

\footnotetext{
${ }^{19}$ Brumberg, 46.

${ }^{20}$ Park, 154.

${ }^{21}$ Houppert, 14.

22 See figure 6.
} the prototype of the first advertisement was much different, centered more on the male importance of the product. Even the tag line read: “To Save Men's Lives Science Discovered Kotex." 22 There was no mention of the product's use or necessity, only a description of its material and where one could purchase it. Furthermore, the ad reinforced how it benefited men and that, with the end of the war, they passed on the same 'comfort' and 'safety' onto women.

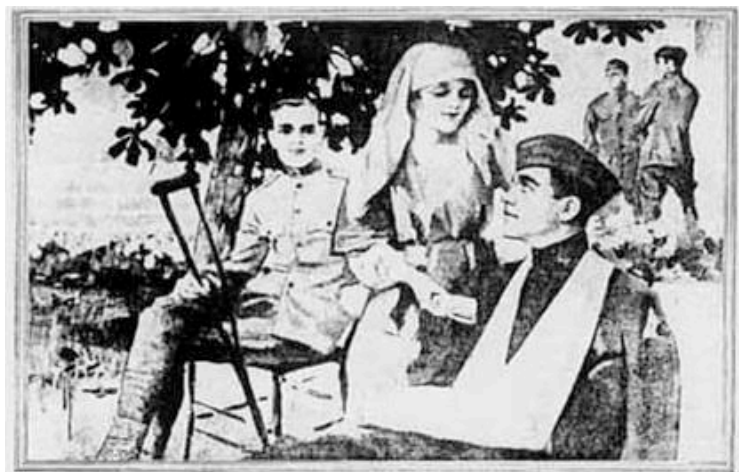

To Save Men's Lives Science Discovered

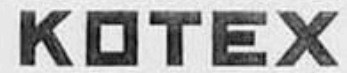

O

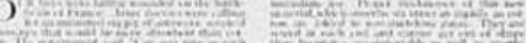

A War Emerency

4.

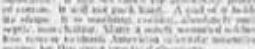

Permenent Peace-Time Utiaty

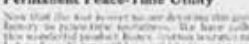

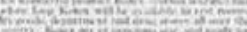

Cellucotton Products Company

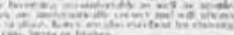

The Cout is Almoet Nothiez
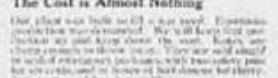

Inexpensive, Comfortable, Hysienic and Safe - KDTEX

Figure 7: Kotex prototype advertisement (1920s). 


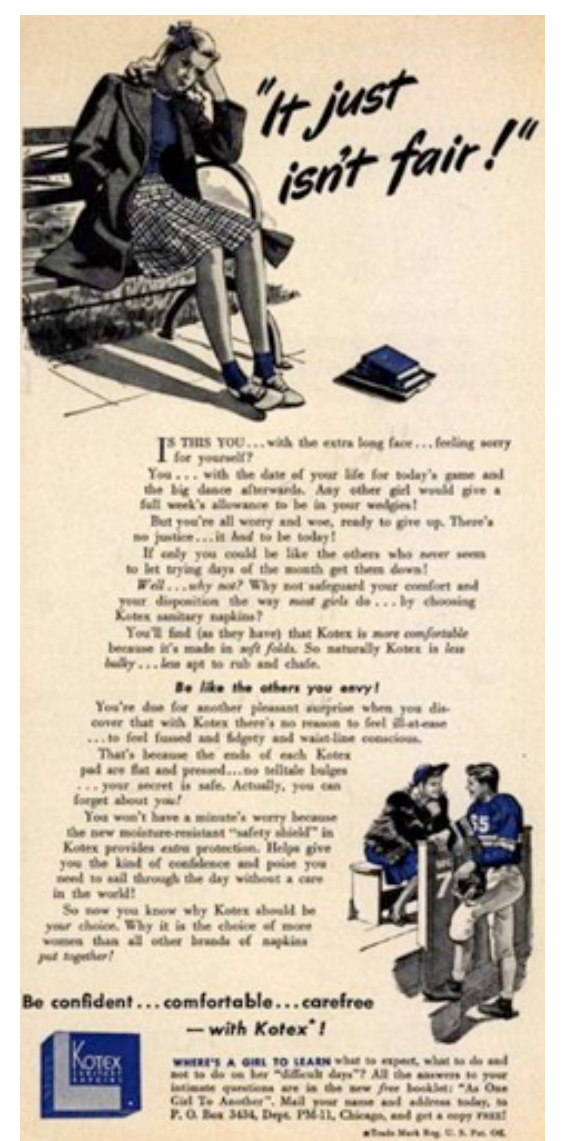

Figure 8: Kotex advertisment, general magazine placement (1941).

effects of the Great Depression. ${ }^{23}$ Moreover, prices steadily decreased, making sanitary napkins increasingly available to lower-class women. ${ }^{24}$ These early products were primarily marketed to women with disposable incomes: a small niche market of middle to upper class white women. The women of the advertisements played into the appeals of modernity and upper class. They were exclusively white, well dressed and seemingly high status, often shown on vacation or engaging in other leisurely activities. An ad proclaimed "8 out of 10 better class women employ it. Proves the folly of old ways!" 25 As a result, commercially made sanitary products became a badge of Americanization among the immigrant and working class. ${ }^{26}$

In 1936, a new innovation was welcomed into the feminine hygiene industry: the commercialized tampon. With it came a new term in the menstruation discourse, freedom. These products were marketed as freeing women from the bondage of odour, belts, pads and pins, allowing them to remain active while being even more discrete about their menstruation. ${ }^{27}$ Harkening back to the concerns of the first ads, Tampax was a hygienic, sanitary option, "making daintiness possible at all times." ${ }^{28}$ Initially, Tampax was marketed exclusively towards married women; menstruation was seen as

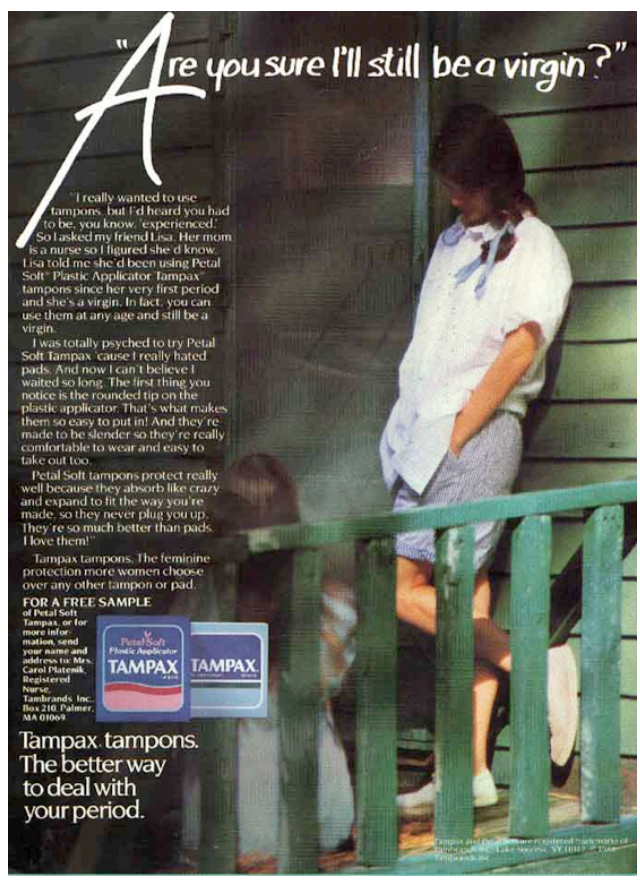

Figure 9: Tampax advertisement, general magazine placement (1990).

${ }^{23}$ J. Farrell-Beck and L. K. Kidd, "The Roles of Health Professionals in the Development and Dissemination of Women's Sanitary Products, 1880-1940" Journal of History of Medicine and the Allied Sciences 51 (1996): 351.

${ }^{24}$ J. Farrell-Beck and L. K. Kidd, 350.

${ }^{25}$ Susan Kim and Elissa Stein, Flow: The Cultural Story of Menstruation, (New York: St. Martin's Griffin, 2009), 20; Linton, 103.

${ }^{26}$ Brumberg, 41.

${ }^{27}$ Kissling, 14.

${ }^{28}$ Tampax was far more successful in its tampon sales than Kotex for one very simple reason - it owned the patent for the applicator, therefore in order to use other brands, such as Kotex's Fibs, a woman would have to touch herself. See figure 7. 
the irrepressible evidence of sexual maturity, which was a characteristic only appropriate for married women. ${ }^{29}$ Furthermore, concerns of tampons breaking young girls' hymens was a serious topic of discussion as late as 1990 (see figure 8). However, students and women working outside the home embraced the product much quicker, recognizing its 'liberating' capabilities. ${ }^{30}$ As women were rushed from the factory back into the domestic sphere by the late 1940s, the discourse surrounding menstruation reflected the current ideologies of the time. Although a majority of women returned to the domestic sphere, many stayed in the workforce; however, they were still seen as inferior to male workers, primarily because of their biological burden. With a variety of menstrual products readily available to most women, menses was no longer an adequate excuse for the mid-century woman who was expected to be socially active and never miss a day of work, whether in the home or at the office. ${ }^{31}$ With the re-introduction of neo-Freudian theories, the majority of personal female concerns were passed off as purely psychological and an "unhealthy attitude towards femininity." 32 Naturally, advertisers were quick to assimilate these new understandings of femininity into marketing strategies. No longer were women physically inept, but mentally unstable; again, menstruation was seen as a destroyer of femininity. ${ }^{33}$ Furthermore, Kotex products were not just advertised as convenient consumer products, but rather, a confidence boost that could be used to bridge any gap in gender discrimination. As seen in this enlargement of a previous image, the everwatchful gaze of a male onlooker is visible in the background. Clearly, regardless of her apparent menstruation she is able to enjoy leisure activities but the image implies a sub-textual lack of confidence. Without the product, the woman could not possibly enjoy herself to the same degree. It is not explicitly stated, but Kotex is the solution for her problems.

By the 1950s, mothers began disappearing from menstrual ads in order to encourage a new, young and autonomous consumer. Previously, Kotex had utilized the familial relationship in their advertising to improve the communication between mother and daughter and, therefore, open their customer market. ${ }^{34}$ Marketers learned early on that brand loyalty was likely to remain strong if a costumer was attracted in adolescence. ${ }^{35}$ This coincided with the introduction of educational programs created

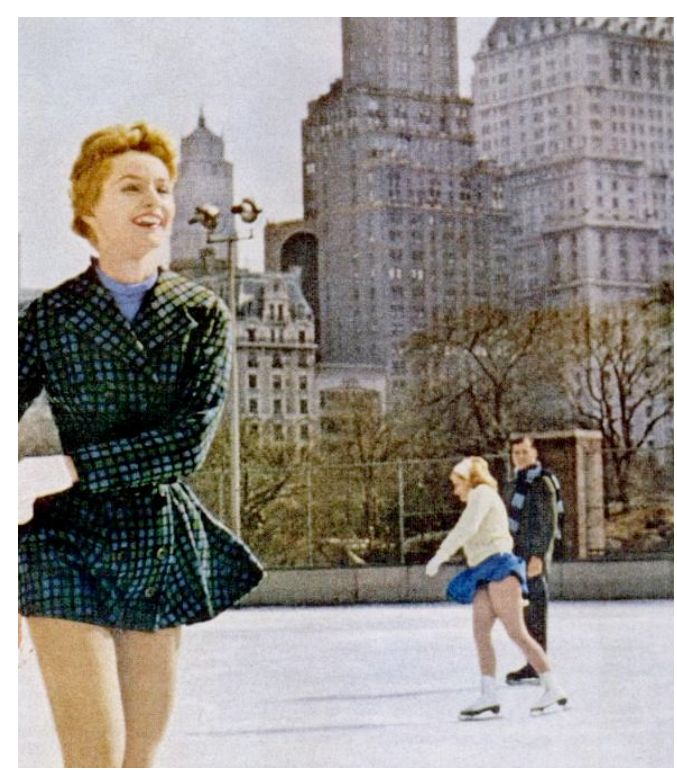

Figure 10: Close-up of previous image.

\footnotetext{
${ }^{29}$ Houppert, 14.

${ }^{30}$ Kim, 123; Kissling, 14.

${ }^{31}$ Park, 156.

${ }^{32}$ Louise Launders, Images of Bleeding: Menstruation as Ideology (New York: Orlando Press, 1988), 58.

${ }^{33}$ Park, 156; Park, 156.

${ }^{34}$ Brumberg, 46-48.

${ }^{35}$ Kissling, 11; Brumberg, 48.

Unfortunately due to strict copyright laws over all Hearst owned magazines, I was unable to access archived advertisements or articles that ran in the popular teen magazine Seventeen.
} 
by the major feminine hygiene companies, which distributed information on menstruation and their products to mothers, teachers, doctors and school nurses. Even Walt Disney was commissioned to make the first corporate-sponsored film The Story of Menstruation (1946), which was seen by approximately 93 million American women and girls. ${ }^{36}$ Presumably, black women and girls were also exposed to this film, although they are not referenced specifically.

The decade of the 1960 s represented the first critical shift in the menstrual product industry. Again, taking cues from the contemporary ideologies of the time, advertisements and educational pamphlets changed their campaigns, and incorporated images of African American girls and women. This also marked the first definitive discourse surrounding African American women as users of sanitary products and as a viable consumer market for Kotex. Black women were barely portrayed in any aspect of print media. In one study analyzing magazines from 1946 to 1969 , it was found that black models comprised less than one-third of $1 \%$ in total advertisements among the pages of major magazines. ${ }^{37}$ If they were shown, they were stereotyped as exotic and sexualized objects, "Mammy's," or otherwise inferior to a white authority figure. ${ }^{38}$ Furthermore, even in magazines run by African Americans, such as Ebony, black models were lighterskinned and were seen enjoying the

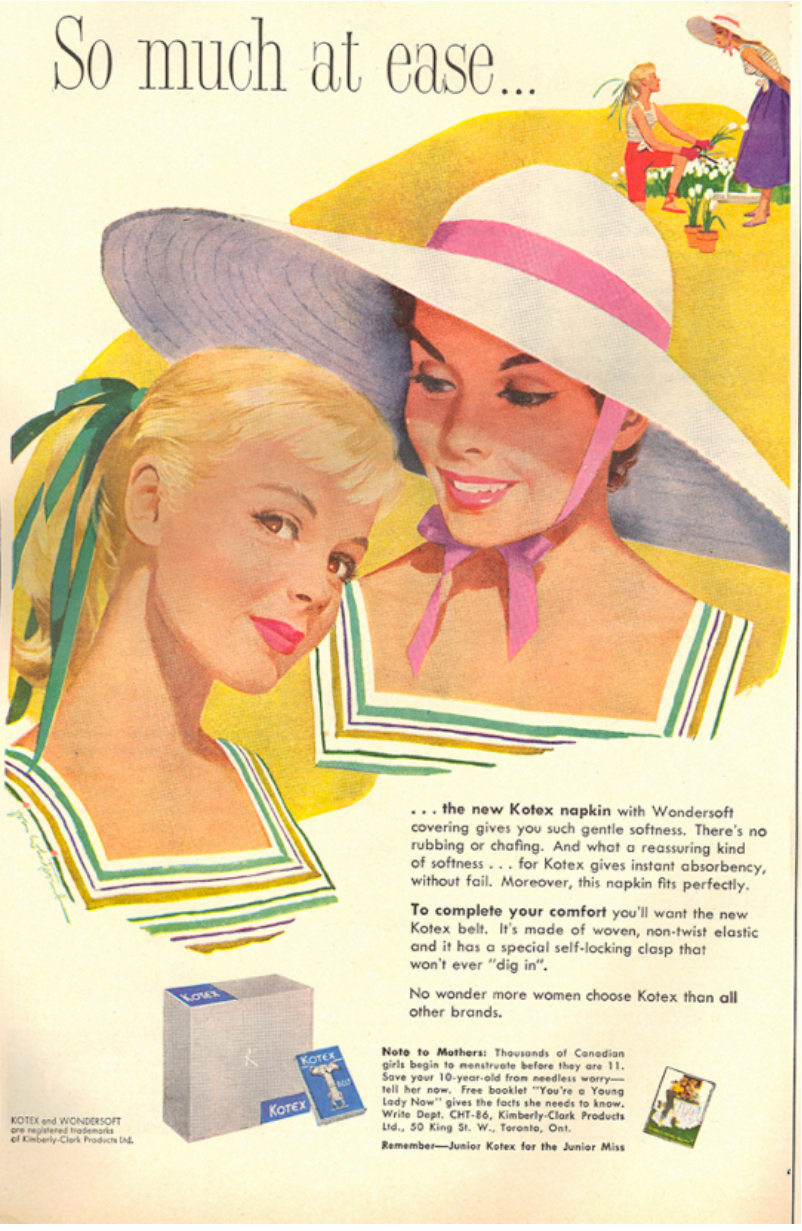

Figure 11: Kotex advertisement, Chatelaine (July 1959). comfort of middle class status and consumerism. ${ }^{39}$

Disenfranchised groups gained new visibility due to the cultural changes brought on by the Civil Rights movement. In terms of consumerism in the United States, the damages of segregation had become most evident during these years, especially when Black Nationalists promoted support for only businesses run by African Americans. ${ }^{40}$ In 1955 and 1956,

\footnotetext{
${ }^{36}$ Brumberg, 137.

${ }^{37}$ An example of the popular magazines analyzed: Life, Vogue and Popular Mechanics etc.

Jennifer E. Millard and Peter R. Grant, "The Stereotypes of Black and White Women in Fashion Magazine

Photographs: The Pose of the Model and the Impression She Creates," Sex Roles 54 (2006): 661.

38 Millard, 661.

${ }^{39}$ Haidarali, 540.

${ }^{40}$ Vostral, 141.
} 
African Americans were known for successfully organizing boycotts, (such as the Montgomery bus boycott) to negatively affected many white-run businesses. Prejudice and discrimination against black people was still rampant; they were not perceived as a financially viable market. However, in 1964, it was estimated that African American buying power exceeded more than 22 billion dollars annually. ${ }^{41}$ Moreover, their successful boycotts and demonstrations proved that as a group, they could yield great consumer strength; it was in Kotex's best interests to research this untapped consumer market.

Newspapers and magazines run by African Americans were characterized as openly critical of government policies, both federal and local, and enjoyed a relatively high degree of freedom of expression, mostly because they were widely ignored by the white population; however, Ebony was much different. ${ }^{42}$ As the first popular African American magazine, it was meant to be the black equivalent to Life, displaying consumerism and prosperity as the dominant ideals of its middle-class black readers. ${ }^{43}$ For this reason, companies such as Kimberly-Clarke were perfectly aware of how to accurately market toward black women in Ebony: they would treat them as white women. Kimberly-Clarke could not jeopardize their current clientele, and a "softening' of the Negro market" was adopted. ${ }^{44}$

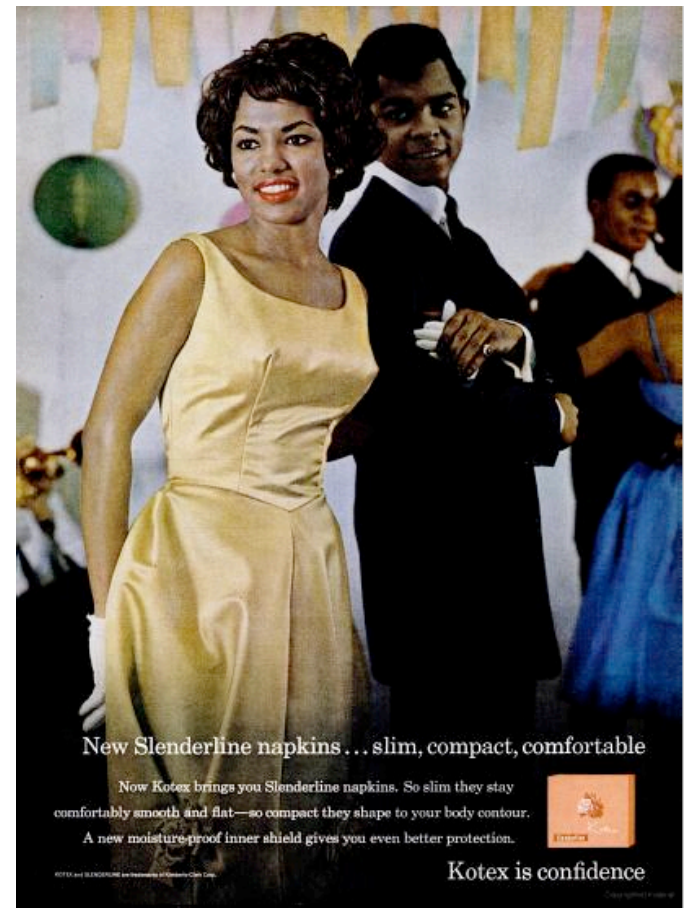

Figure 12: Kotex advertisement, Ebony (1962).
Notably, prior to these serious studies of African American consumerism, Kotex began employing a technique called "duplicate advertising," the act of replacing white models with African American ones. This kept advertising costs low, "while layout and planning remained the same, the only necessary change was the model." Through my analysis of Ebony magazine between the years of 1959 and 1969, Kotex was not the only feminine hygiene manufacturer to introduce advertisements with black models, but they were the only ones who presented full page, glossy spreads to publicize their product.

For example, figures twelve and thirteen were both taken from the April 1962 edition of Ebony and upon immediate inspection there is an obvious difference between the two advertisements. One is a full-page color ad featuring a glamorous young woman at a party, whereas the other is simplistic, and black and white. Judging by the comparison of these two ads, Kotex would become the preferred brand

\footnotetext{
${ }^{41}$ Vostral, 143.

42 Ibid.

${ }^{43}$ Haidarali, 539.

44 Vostral, 143.
} 
for middle-class, consumer-minded African American women. ${ }^{45}$

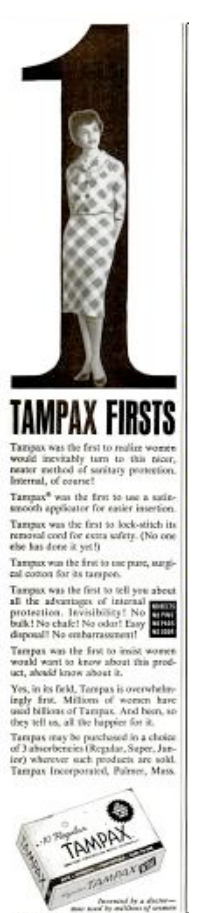

Figure 13:

Kotex

advertisement, Ebony (1962).

It was not until May 1969 that Kotex's competitor, Tampax, employed "duplicate advertising" techniques in their "freedom" campaigns. Interestingly enough, the term "freedom" had been associated with Tampax since it was first commercially advertised in 1932, but was in no way a reference to the Civil Rights movement. In fact, both Kotex and Tampax avoided images commonly associated with the movements of the time, such as images of clenched fists in the air, believing these images were too dangerous for mainstream advertisements that still catered to the white consumer. ${ }^{46}$

For the companies, "duplicate advertising" was a simple and inexpensive means of advertising to a new market. By using lighter skinned models, white advertisers, would not disrupt the dominant middleclass, white aesthetic of contemporary America. ${ }^{47}$ Advertisers assumed that African American women's ideologies concerning menstrual products were exactly the same as white women's ideologies, implying black people were incapable of making their own decisions when choosing consumer products. On the other hand, as Laila Haidarali points out in her article, "Polishing Brown Diamonds," for Ebony readers, the effects of "duplicate advertising" were profound. It illustrated that African American people could successfully be shown in the same psychic spaces as whites, "thus mediating the racial divide emblematic of the American social order." 48 Moreover, these women were not shown in the stereotypical roles discussed earlier. This is best illustrated in Kotex's 1969 campaign (see figures 14 and 15) where, although the "duplicate" technique is utilized, the images are much stronger than any that had preceded them. Not only were the types of products different, the whole structure of the advertisements changed. The text took up far less space on the page, centering all the attention on the single models, which were exceptionally glamorous and fashionable. Both women are shown staring sharply through the camera, which was a departure from previous years of youthful coyness. These women were represented as strong, confident, self-assured and independent,

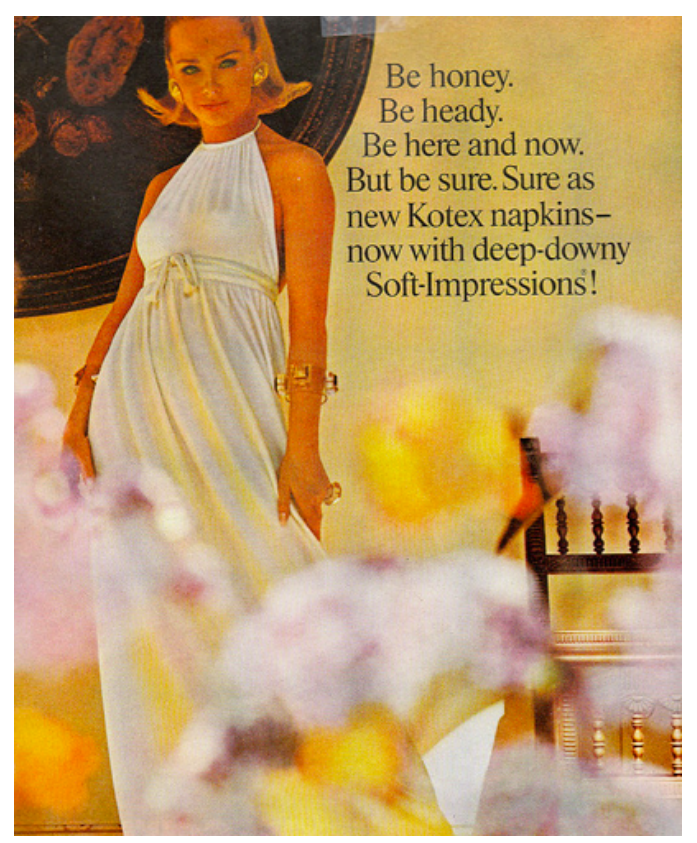

Figure 14: Kotex advertisment, general

${ }^{45}$ Future analysis would benefit from multi-racial statistics concernire brand loyalty, which could potentrally lead a researcher to fully understand what advertisements werempgazine placement epective to persuade the African

American consumer.

${ }^{46}$ Vostral, 143.

${ }^{47}$ Haidarali, 537.

${ }^{48}$ Haidarali, 540. 
a stark contrast to women of earlier advertisements. These images also demonstrate the changing focus in society as women moved away from dutiful housewife to independent, powerful players in the public sphere. Both women in the below examples positively depict the changing position of women in society, celebrating independence and femininity without the affirmation of male domination or racial stereotypes.

We see a definitive shift in the 1960s with more fierce and independent women modeling in Kotex's advertisements, but these improvements were quickly overshadowed by the introduction of television advertising. ${ }^{49}$ Due to the code of standards for television commercials, it was not until 1972 that products related to internal bodily functions were permitted to air. ${ }^{50}$ Even then, strict rules and regulations surrounding what could be said restricted companies' actions even further and menstrual products were once again something inviting discreteness and disgust.

In Kimberly-Clarke's newest ad campaign "U by Kotex," advertisers try to "break the cycle" surrounding the discussion of menstruation and the products associated with it. ${ }^{51}$ The campaign parodies pre-existing conventions, and attempts to make an impression with marketing that is more straightforward. Upon arrival to their website, you are encouraged to sign a "Declaration of Real Talk:" a vow to defy the societal pressures of speaking about one's body and health. Furthermore, there are videos parodying contemporary menstruation advertisements and one of an actress teaching girls how to insert a tampon for the first time using anatomically correct pictures and a plush vagina. The website also features videos they call "social experiments," including one of an actor asking strangers in a supermarket for help choosing the right products for his girlfriend. ${ }^{52}$ Ironically, the same company that first manufactured menstruation as a female problem is the same one making an effort towards liberation from this discourse.

One question arising from Kotex's new " $U$ " campaign is whether it is a response to contemporary consumers' hypercritical reactions toward media and culture, or a mimicking of the current ideologies in order to sell a product. Just as the introduction of African American women into advertisements in the 1960s extended the targeted demographic, the " $U$ "

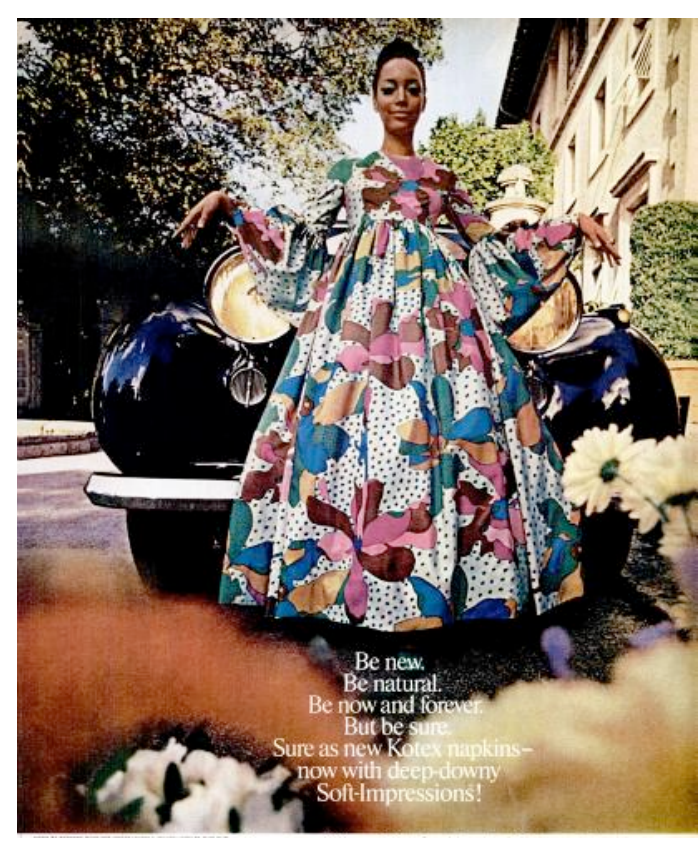

Figure 15: Kotex advertising, Ebony (July 1969).

\footnotetext{
49 Vorstal, 147.

${ }^{50}$ Levine, 40.

${ }^{51} \mathrm{http}: / /$ www.ubykotex.com/get_real/view

I also suggest watching two of their commercials: http://www.youtube.com/watch?v=lpypeLL1dAs and http://www.youtube.com/watch?v=QOM4AMV050A\&feature=related

${ }^{52} \mathrm{http}: / / w w w . y o u t u b e . c o m / u s e r / k c 10 u b y k o t \# p / a / u / 0 / n 09 S e j x p c F A$ and http://www.youtube.com/user/kc10ubykot\#p/u/6/PF0QL93IXqE
}

Constellations

Volume 2, No. 2 (Winter 2011) 
campaign is a deliberate approach to widen their consumer market. By parodying the same discourse they maintained for most of the 20th century, they offer new way for consumers to view their product.

The modern woman's relationship with her body has been largely defined through consumer products and advertisements, and this commercial exploitation of menstrual products is no exception. ${ }^{53}$ These products have given women an inexpensive and superior management technique to that of women of the past. With a movement towards a more open discourse on menstruation, women have gained better comfort, effectiveness and mobility from these products. However, advertisements continually bombard women with images promoting freshness, freedom and femininity, perpetuating the myth that without a certain product, women lack the ability to 'overcome' their apparent debilitating bodily function. ${ }^{54}$ Beginning with the earliest Kotex advertisements, discussion focused on restraint and secrecy surrounding women's natural bodily functions. Advertisers boasted: "not once in any advertisement to women, have we discussed Kotex as a Sanitary Napkin!" 55 However, by responding to the changing ideologies of the time, we have seen how Kotex advertisements have evolved. They have transitioned from displaying wealthy, upper class white women to younger and independent black women. Despite overall changes in representation in advertising, the secretive language has stayed the same. Women may appear stronger and more independent, yet the discourse itself has not fluctuated. Nowhere is there mention of 'period,' 'menstruation,' or 'blood;' take away the brand name and any image could easily pass as a fashion advertisement. Words such as "secret" and "problem" are still found throughout menstrual advertising today and continue to imply a disorder within the female body, making it different, unclean and undesirable. Without an open forum in which to discuss menstruation, menstrual products and the way they are advertised, we perpetuate the same myths and taboos we try to disprove, only adding to the level of confusion and frustration that accompanies womanhood in our modern world.

${ }^{53}$ Kissling, 123.

54 Ibid.

${ }^{55}$ Houppert, 14.

Constellations

Volume 2, No. 2 (Winter 2011) 


\section{Bibliography}

Brumberg, Joan Jacobs. The Body Project: An Intimate History of American Girls. New York: Random House, 1997.

Cornell-Chuppa, Kim. "Filling a Vacuum: Women's Health Information in Good Housekeeping's Articles and Advertisements, 1920-1965." The Historian (2005): 454-473.

J. Farrell-Beck and L. K. Kidd. "The Roles of Health Professionals in the Development and Dissemination of Women's Sanitary Products, 1880-1940" Journal of History of Medicine and the Allied Sciences 51 (1996): 325-352.

Haidarali, Laila. "Polishing Brown Diamonds: African American Women, Popular Magazines, and the Advent of Modeling in Early Postwar America." In: Unequal Sisters: An Inclusive Reader in U.S. Women's History $4^{\text {th }}$ ed. Edited by Vicki L. Ruiz and Ellen Carol DuBois. New York: Routledge, 2008.

Houppert, Karen. The Curse: Confronting the Last Unmentionable Taboo: Menstruation. New York: Farrar, Straus and Giroux, 1999.

Kim, Susan and Elissa Stein. Flow: The Cultural Story of Menstruation. New York: St. Martin's Griffin, 2009.

Kissling, Elizabeth Arveda. Capitalizing on the Curse: The Business of Menstruation. Boulder: Lynne Rienner Publishers, 2006.

Launders, Louise. Images of Bleeding: Menstruation as Ideology. New York: Orlando Press, 1988.

Levine, Elana. “'Having a female body doesn't make you feminine”: Feminine Hygiene Advertising and 1970s Television." The Velvet Light Trap 50 (Fall 2002): 36-47.

Linton, David. "Men in Menstrual Product Advertising - 1920-1949." Women and Health 46 (2007): 99-114.

Millard, E. Jennifer, Peter R. Grant. "The Stereotypes of Black and White Women in Fashion Magazine Photographs: The Pose of the Model and the Impression She Creates." Sex Roles 54 (2006): 659-673.

Park, Shelley M. "From Sanitation to Liberation?: The Modern and Postmodern Marketing of Menstrual Products." Journal of Popular Culture (2003): 149-167.

Vostral, Sharra L. Under Wraps: The History of Menstrual Hygiene Technology. Lanham: Lexingtion Books, 2008.

\section{Figure Sources}

Figure 1: Original Kotex advertisement, general magazine placement, 1964. (Online Image) http://www.flickr.com/photos/mrstitustrout/4640051733/in/faves-ninakulhawy/

Figure 2: Original Kotex advertisement, Ebony, November 1962. (Online Image) http://www.ebonyjet.com/Archive.aspx

Figure 3: Original Kotex advertisement, Ebony, November 1959. (Online Image) http://www.ebonyjet.com/Archive.aspx

Figure 4: Original Lysol advertisement, general magazine placement, year unknown. (Online Image) http://www.flickr.com/photos/51035667177@N01/59374285

Figure 5: Original Kotex advertisements, Saturday Evening Post, 1927. (Online Image) http://library.duke.edu/digitalcollections/adaccess_BH0247/

Constellations

Volume 2, No. 2 (Winter 2011) 
Figure 6: Original Kotex advertisement, Ladies Home Journal, January 1921. (Online Image) http://www.mum.org/kotexadwords.htm

Figure 7: Kotex prototype advertisement, 1920s. (Online Image) http://www.mum.org/kotexadwords.htm

Figure 8: Original Kotex advertisement, general magazine placement, 1941. (Online Image) http://www.mum.org/urkotex.htm

Figure 9: Original Tampax advertisement, general magazine placement, 1990. (Online Image) http://www.mum.org/tamvirad.htm

Figure 10: Close-up of Image 3.

Figure 11: Original Kotex advertisement, Chatelaine, 1959. (Online Image) http://finalfashion.ca/category/tearsheets/

Figure 12: Original Kotex advertisement, Ebony, April 1962. (Online Image) http://www.ebonyjet.com/Archive.aspx

Figure 13: Original Tampax advertisement, Ebony, April 1962. (Online Image) http://www.ebonyjet.com/Archive.aspx

Figure 14: Original Kotex advertisement, general magazine placement, 1969. (Online Image) <http://www.flickr.com/photos/29176016@N04/2857633641/lightbox/>

Figure 15: Original Kotex advertisement, Ebony, July 1969. (Online Image) http://www.ebonyjet.com/Archive.aspx 